\title{
Peran Sociological Jurisprudence Dalam Menciptakan Keefektivitasan Hukum Melalui Living Law
}

\begin{abstract}
Wempy Setyabudi Hernowo'), Zaid ${ }^{2)}$, M. Aufar Saputra Pratama Erawan')
${ }^{1}$ Magister Hukum, Universitas Muhammadiyah Yogyakarta, Jl. Brawijaya, Kasihan, Bantul, D.I. Yogyakarta 55183

${ }^{2}$ Magister Hukum, Universitas Muhammadiyah Yogyakarta, Jl. Brawijaya, Kasihan, Bantul, D.I. Yogyakarta 55183

${ }^{3}$ Magister Hukum, Universitas Muhammadiyah Yogyakarta, Jl. Brawijaya, Kasihan, Bantul, D.I. Yogyakarta 55183 Correspondence email: wempy.setyabudi@yahoo.com; email: zaidrusdianto@gmail.com; email: m.aufar.psc20@mail.umy.ac.id

Abstrak. Konsep ilmu Sociological jurisprudence berpandangan bahwa Sebagai produk yang diciptakan oleh masyarakat, hukum juga bertujuan untuk melindungi kepentingan dan memuaskan masyarakat yang pada akhirnya menjadi sarana untuk mengontrol masyarakat itu sendiri. Tujuan kajian atau penelitian dalam artikel ini adalah untuk mencapai tujuan tersebut secara efektif. Melalui metode penelitian doktrinal dengan pendekatan konseptual dan perundang-undangan, maka hasil dan temuan dalam penelitian ini menunjukkan bahwa hukum yang efektif adalah hukum menjalankan fungsi-fungsinya dengan baik dan benar. Dan untuk mencapai itu, keefektivitasan hukum dapat direalisasikan melalui empat hal, yaitu dengan nilai-nilai yang berlaku di masyarakat, fakta-fakta sosial, aspiras-aspirasi masyakarat dan juga kepentingan-kepentingan masyarakat dalam pembuatan, penafsiran, hingga penerapan peraturan-peraturan Hukum terhadap masyarakat.
\end{abstract}

Kata Kunci: Sociological Jurisprudence; Living Law; Keefektivitasan Hukum.

Abstract. The concept of Sociological jurisprudence has the view that as a product created by society, law also aims to protect the interests and satisfy society, which in turn becomes a means of controlling society itself. The purpose of the study or research in this article is to achieve these goals effectively. Through doctrinal research methods with a conceptual and statutory approach, the results and findings of this study indicate that effective law is the law that carries out its functions properly and correctly. And to achieve that, the effectiveness of the law can be realized through four things, namely by the values prevailing in society, social facts, the aspirations of the community and also the interests of society in the making, interpretation, and application of legal regulations against Public.

Keywords: Sociological Jurisprudence; Living Law; The Effectiveness of Law

\section{PENDAHULUAN}

Setiap manusia memiliki kepentingan, dan seiring dengan dimana adanya kepentingan, maka di sana akan selalu ada yang mengancam akan kepentingan tersebut. Sebagai konsekuensi dari makhluk sosial (zoon politikon), manusia membentuk kelompok dan bermasyarakat untuk melindungi kepentingan-kepentingannya tersebut. Sehingga manusia membuat aturan hukum atas kepentingan itu, manusia membuat aturan hukum yang disebut dengan norma dan kaedah sosial. Sehingga manusia membuat aturan hukum atas kepentingan itu, manusia membuat aturan hukum yang disebut dengan norma dan kaedah sosial. Seiring berjalannya waktu hukum ini terus melekat pada masyarakat, sehingga dimana ada masyarat di situ pasti ada hukum yang mengaturnya (ubi societas ibi ius) ${ }^{1}$. Dan dimana ada hukum disitu ada masyarakat (ubi ius ibi societas) ${ }^{2}$. Hanya saja hukum tidak akan pernah berjalan dengan sendirinya, perlu adanya kreator, supporter, koordinator unifikator dan motor dalam proses-prosesnya. Dan kekuasaan adalah instrumen penting bagi hukum untuk memastikan itu semua. karena biar bagaimanapun juga hukum tidak akan berjalan tanpa adanya kekuasaan. Sehingga hukum memerlukan kekuasaan dan begitupun sebaliknya. Oleh karenanya Mochtar Kusumaatmadja memberikan kutipan bahwa "hukum tanpa kekuasaan adalah angan-angan, sedangkan kekuasaan tanpa hukum adalah kezaliman"3. Hal serupa diungkkapkan pula oleh Sudikno Mertokusumo bahwa pada hakikatnya hukum itu adalah kekuasaan itu sendiri, karena hukum memiliki fungsi dari kekuasaan ${ }^{4}$. Oleh karenanya hukum itu berkuasa yang salah satu lingkup kekuasaannya adalah kekuasaan itu sendiri. Sehingga hukum harus tetap berdaulat dan berada

\footnotetext{
${ }^{1}$ Sudikno Mertokusumo. “Mengenal Hukum: Suatu Pengantar”, (Yogyakarta: Libert, 2008) hlm. 1-4.

${ }^{2}$ Andrea Salvatore. 2018. "A Counter-Mine That Explodes Silently: Romano and Schmitt on the Unity of the Legal Order." Ethics and Global Politics Vol. 11, No. 1, (2018): 51.

${ }^{3}$ Mochtar Kusumaatmadja, "Fungsi dan Perkembangan Hukum dalam Pembangunan Nasional”. (Bandung: Bina Cipta, 1976), hlm. 5.

${ }^{4}$ Sudikno Mertokusumo, Op. Cit., hlm. 20.
} 
di atas kekuasaan sebagai payung yang menjadi konsep dasar dari rule of law di dalam Rechtsstaat ${ }^{5}$, bukan menjadi sandal kekuasaan yang berpotensi melahirkan konsep dasar dari rule by law di dalam Obrigkeitsstaat ${ }^{6}$.

Berdasarkan Undang-Undang Dasar Negara Republik Indonesia Tahun 1945 menyebutkan bahwa konsep negara Indonesia pada pasal 1 (3) adalah sebagai negara hukum. Meskipun makna dari negara hukum ini multi prespektif dan multi dimensi, tetap saja secara perumusan mengacu pada eropa kontinental, dan secara falsafah dan ideologi mengacu pada Pancasila. Secara sistem, Indonesia menganut sistem civil law yang dalam perkembanganya sampai saat ini mencoba mengadopsi apa yang sudah menjadi ciri khas dari common law yaitu the living law yang pada dasarnya bukanlah sesuatu yang asing bagi bangsa Indonesia ${ }^{7}$. Namun semenjak penguasa (pembuat hukum) membuat hukum dengan semena-mena, Membuat keputusan secara subjektif, dan membangun sistem yang tidak simetris. Maka menimbulkan ketidak percayaan pada masyarakat ${ }^{8}$. Dan ketika masyarakat sudah tidak memiliki kepercayaan terhadap hukum yang dibuat oleh penguasa maka fungsi hukum tidak akan berjalan dengan baik dan tujuan hukum tidak akan tercapai ${ }^{9}$. Terlebih lagi, tidak jarang penguasa menggunakan kekuasaannya untuk memaksa yang dengannya agar hukum dapat dipatuhi. Dan hal ini menurut Satjipto Rahardjo telah menjadi ciri dari suatu hukum dan semakin kuat ketika diterapkan dalam negara modern ${ }^{10}$.

Kefektifan hukum tercermin pada bagaimana hukum menjalankan fungsi-fungsinya dengan baik dan benar. Fungsi hukum di sini adalah bagaimana menciptakan ketertiban-ketertiban di dalam dan mengendalikan sosial. Terkadang dalam negara modern barat, sering kali menggunakan paksaan dan sanksi-sanksi dalam penegakannya. Hal ini tentu akan menimbulkan ketidak sukaan masyarakat, ketidak adilan dan ketidak benaran dalam menjalankan fungsi hukum. Sehingga dampaknya adalah bukan menyelesaikan konflik, justru menimbulkan konflik dan pemberontakan ${ }^{11}$. Oleh karenanya, keefektivitasan hukum pada dasarnya memfokuskan pada hukum dan masyarakat yang menjadi objeknya. Sehingga keefektivitasan hukum tidak dilihat dari sisi fungsi pengaturan hukum semata, melainkan juga dari sisi fungsi manusianya. Tidak pula hanya dilihat dari sisi kehadiaran hukumnya, melainkan juga kesiapan masyarakat untuk mematuhinya ${ }^{12}$. Dan di sinilah menurut James G. March bahwa pengetahuan hubungan hukum dengan masyarakat harus lebih ditingkatkan ${ }^{13}$.

Di samping itu, ilmu Sociological jurisprudence yang sampai saat ini masih terus menunjukkan tanda-tanda kebangkitannya ${ }^{14}$ yang secara aspek fungsionalis berfungsi menganalisis konteks sosial di mana tuntutan hukum terjadi dan bagaimana aturan hukum dapat mempengaruhi interaksi sosial ${ }^{15}$. Sociological Jurisprudence juga berpandangan bahwa bagaimana menciptakan peraturan hukum dapat dijalankan secara mutlak tanpa harus paksaan, melainkan melalui struktur sosial di mana hukum itu dijalankan ${ }^{16}$. Di sisi lain, Memasukkan living law dalam pembangunan hukum nasional merupakan suatu kebijakan yang perlu ditekankan demi terciptanya hukum nasional yang benar-benar mampu menjadi solusi keefektivitasan aturan hukum bagi seluruh masyarakat Indonesia yang memiliki latar belakang dan kebutuhan hukum yang berbeda-beda ${ }^{17}$ sebagaimana tujuan dari artikel ini.

\section{METODE}

\footnotetext{
${ }^{5}$ Martin Krygier. "Rule of Law (and Rechtsstaat).” dalam James Wright (Eds), International Encyclopedia of the Social \& Behavioral Sciences: Second Edition (Amsterdam: Elsevier, 2015), hlm. 782.

${ }^{6}$ Ronan Cormacain. "Legislation, Legislative Drafting and the Rule of Law." Theory and Practice of Legislation Vol. 5, No. 2, (2017): 7.

${ }^{7}$ Hwian Christianto, "Measuring Cyber Pornography Based on Indonesian Living Law: A Study of Current Law Finding Method." International Journal of Law, Crime and Justice Vol. 60, (2020).

${ }^{8}$ Satjipto Rahardjo. "Hukum dan Perilaku: Hidup Baik adalah Dasar Hukum Yang Baik”. (Jakarta: PT. Kompas Media Nusantara, 2009), hlm. 93.

${ }^{9}$ Diego Babuder. "Legal Evolution of the Concept of 'Home Base' for the Purpose of Determining Labour and Social

Security Law Applicable to European Aircrew Members.” Journal of Air Transport Management Vol. 92, (2021).

${ }^{10}$ Rahardjo, Satjipto. “Sosiologi Hukum: Perkembangan, Metode, dan Pilihan Masalah". (Surakarta: Muhammadiyyah University Press, 2002), hlm. 186.

${ }^{11}$ Griffiths, John. "What Is Sociology of Law? (On Law, Rules, Social Control and Sociology)." Journal of Legal

Pluralism and Unofficial Law Vol. 49, No. 2, (2017): 142.

12 Satjipto Rahardjo, 2002, Op.Cit., h. 188.

${ }^{13}$ James G. March. "Sociological Jurisprudence Revisited, A Review (More or Less) of Max Gluckman”. Stanford Law Review, Vol. 8, No. 3, (1956): 534.

${ }^{14}$ F. H.Buckley. "The Revival of Sociological Jurisprudence”. The Journal of Socio-Economics, Vol. 22 No, 4 (1993): 197.

${ }^{15}$ Langone, Richard. "The Science of Sociological Jurisprudence as a Methodology For Legal Analysis". Touro law review, Vol. 17, No.5, (2016): 800.

${ }^{16}$ Muhammad Junaidi. "Semangat Pembaharuan Dan Penegakan Hukum Indonesia Dalam Perspektif Sociological Jurisprudence". Jurnal Pembaharuan Hukum. Vol. 3, No. 1, (2016): 53.

17 Hamzani, A.I., dkk. "Considering the Living Law as A Source in National Legal Development". Jurnal Cita Hukum, Vol. 7, No. 2, (2019):190.
} 
Penelitian ini menggunakan metode penelitian hukum doktrinal melalui pendekatan konseptual dan pendekatan perundangang-undangan yang dianalisis secara preskripsi. Metode doktrinal merupakan metode penelitian dalam hukum yang menjadikan doktrin yang dipahami oleh peneliti sebagai konsep dasarnya ${ }^{18}$.

Sedangkan pendekatan konseptual sering kali dipakai dalam penelitan yang bersifat doktrinal karena pendekatan ini mendasarkan pada doktrin yang berkembang dalam ilmu hukum untuk dijadikan sebagai pijakan argumentasi. Selain pendekatan konseptual, penulis juga menggunakan konsep perundang-undangan untuk melengkapi dan menyempurnakan argumentasi melalui produk-produk hukum.

Sehingga dalam penelitian inipun bahan hukum yang digunakan berupa bahan hukum primer yang diambil dari peraturan perundang-undangan dan juga bahan hukum sekunder yang diambil dari buku-buku, artikel dan jurnal hukum. Bahan-bahan hukum tersebut kemudian ditelusuri dengan menggunakan tehnik studi dokumen (pustaka) dalam mendapatkan sumber informasi yang berhubungan dengan masalah yang diteliti.

\section{HASIL DAN PEMBAHASAN}

\section{Sekilas Memahami Sociological jurisprudence}

Ilmu filsafat sosiologis hukum atau yang dalam Bahasa Inggris disebut sebagai Sociological jurisprudence (Jerman: Soziologische Jurisprudenz; Prancis: Sociologique; Belanda: Rechtswetenschap) merupakan Modern Theories of Law yang seabad lalu muncul dan mulai dianut oleh masyarakat modern yang demokratis ${ }^{19}$. Sociological jurisprudence juga merupakan bagian dari ilmu filsafat hukum yang fokus utamanya adalah menganalisis tentang pengaruh kausalitas antara hukum dan masyarakat. Sehingga hukum yang hakiki itu adalah hukum yang sesuai dengan nilai-nilai yang melekat pada masyarakat, dan jika hukum ingin diterima dan ditaati, maka hukum tersebut tidak boleh bertentangan dengan nilai-nilai yang sudah hidup di dalam masyarakat.

Terkait konsep Sociological jurisprudence, seorang pemikir sosiologis Austria Eugen Ehrlich (1862-1922) pernah mengungkapkan bahwa "positive law cannot be understood apart from the social norms of the 'living law."' "At the present as well as at any other time, the center of gravity of legal development lies not in legislation, nor in juristic science, nor in judicial decision, but in society itself."20

Pendapat Ehrlich di atas menjadi konsep awal yang paling mendasar dalam Sociological jurisprudence sekaligus menjadikannya sebagai tokoh utama penggagas teori Sociological jurisprudence. Selain Ehrlich, beberapa tokoh intelektual lainnya seperti Friedrich Carl von Savigny (1804-1961), Roscoe Pound (1870-1964), Hans Nawiasky (1880-1961), George Whitecross Paton (1902-1985), Oliver Wendell Holmes Jr (1902-1932) dan Laurence M. Friedmann (1930-sekarang) juga dipercaya sebagai penggagas dari paham aliran dan pemikiran Sociological jurisprudence.

Para tokoh di atas juga telah berperan besar dalam mendefinisikan apa itu Sociological jurisprudence. Roscoe Pound misalnya, Sebagai bapak filsafat sosiologi hukum Pound berpandangan bahwa hukum secara filosofis sosiologis dapat diartikan sebagai "adat kebiasaan sosial yang bertujuan untuk memuaskan masyarakat" 21 . Kepuasan masyarakat ini bisa diraih dengan melihat dari nilai-nilai tercipta dari norma-norma yang sudah ada dan turun temurun hidup dalam masyarakat. Nilai-nilai tersebut yang kemudian menjadi elemen dasar dalam kehidupan sosial yang tidak akan pernah lepas dari masyakarat ${ }^{22}$. Nilai-Nilai yang hidup di tengah masyarakat ini menjadi akar hukum bagi bangsa-bangsa yang menerapkan hukum modern ${ }^{23}$ yang mulai dan sampai saat ini sudah mengenal masyarakat sebagai subjek hukum untuk diterima dan diakui hak, keinginan, dan kepentingan mereka ${ }^{24}$.

Namun sayangnya, Sociological jurisprudence sering kali disalahpahami dan disamakan dengan Sosiologi hukum (Sociology of law) yang pada hakikatnya berbeda. Jika dilihat sepintas mungkin terlihat sama namun pada hakikatnya tidaklah serupa. Meskipun demikian penulis tidak menafikan memang adanya persamaan di antara keduanya. Dimana titik persamaan di antara keduanya adalah sama-sama mempelajari dan menganalisis tentang pengaruh hukum pada

\footnotetext{
${ }^{18}$ Irianto, S., Shidarta. Metode Peneltian Hukum: Konstelasi dan Refleksi. (Jakarta: Yayasan Pustaka Obor Indonesia, 2018),
} hlm. 121.

${ }^{19}$ Přibán̆, J. Roger Cotterrell: Sociological Jurisprudence: Juristic Thought and Social Inquiry. Journal of Law and Society Vol 45 No. 2, (2018): 337.

${ }^{20}$ Bodenheimer, E. Jurisprudence: The Phiolosphy and Method of the Law (London: Harvard University Press, 1947), hlm. 114.

${ }^{21}$ Morrison, W. Jurisprudence: from the Greek to Post-Modernism. (London: Routledge, 2005), hlm. 19.

${ }^{22}$ Wirawan. I.B. Teori-Teori Sosial dalam Tiga Paradigma: Fakta Sosial, Definisi Sosial dan Perilaku Sosial (Jakarta: Kencana, 2012), hlm. 45.

${ }^{23}$ Rahardjo, S. Ilmu Hukum (Bandung: PT. Citra Aditya Bakti, 2012), hlm. 263.

${ }^{24}$ Morrison, Loc.Cit., hlm. 19. 
masyarakat dan sama-sama menggunakan perspektif sosial ${ }^{25}$. Serta sama-sama mengkritik terhadap pemikiran dari aliran formalisme ${ }^{26}$.

Hanya saja, titik persamaan di antara keduanya tidak sebanyak titik perbedannya. Titik perbedaannya adalah pertama dari awal tempat kemunculannya, menurut Georges Gurvitch Sociological jurisprudence muncul pertama kali di Amerika, sedangkan sosiologi hukum awal kemunculannya adalah di eropa ${ }^{27}$. Yang kedua, terletak pada aliran ilmunya dimana Sociological jurisprudence bersumber dari ilmu filsafat sedangkan sosiologi hukum bersumber dari ilmu sosiologi. Ketiga, dari sisi fokus telaahnya, Sociological jurisprudence berfokus untuk menelaah timbal balik antara hukum dengan masyarakat dan juga sebaliknya, sedangkan sosiologi hukum hanya berfokus untuk menelaah pengaruh masyarakat terhadap hukum. Dan terakhir, dari sisi pendekatannya, Sociological jurisprudence menggunakan pendekatan dari hukum kepada masyarakat, sedangkan sosiologi hukum sebaliknya ${ }^{28}$.

Bukan hanya itu, titik perbedaan yang cukup mencolok antara Sociological jurisprudence dan pendekatan teoretis lainnya adalah dapat dilihat dalam 5 poin berikut ini ${ }^{29}$ :

a. Sociological jurisprudence memandang bahwa hukum harus dilihat dari kerja hukum yang sebenarnya bukan sekedar konten metafisis semata;

b. Sociological jurisprudence memandang hukum sebagai pranata sosial yang dapat diusahakan untuk diubah maupun ditingkatkan;

c. Penekanan dan focus dalam Sociological jurisprudence diletakkan pada tujuan sosial hukum;

d. Sociological jurisprudence memandang bahwa sila hukum merupakan panduan untuk menghasilkan keadilan sosial dan kurang sebagai model yang tidak fleksibel;

e. Sociological jurisprudence berpandangan bahwa hukum terdiri dari pandangan filosofis yang beragam, termasuk pragmatisme, dan berbagai aliran filosofis sosiologis dan sosial.

Kesalah pahaman dalam memahami Sociological jurisprudence ternyata bukan hanya terhadap sosiologi hukum semata, Roscoe Pound melihat bahwa sebagaian ahli dan sarjana memandang dan beranggapan bahwa Sociological jurisprudence adalah turunan dari madzhab positivism, karena dianggap memiliki kesamaan dengan pemikiran penggagas madzhab positifism Auguste Comte (1798-1857). Sebagiannya lagi memandang sebagai anthropological ethnology yang berarti ilmu hukum dengan kearifan antropologi dan etnologi. Masalah inilah yang pada akhirnya membuat Pound memberikan penjelasan dan menjabarkan kembali tujuan dari Sociological jurisprudence yang berdasarkan pada fakta-fakta sosial yang menjadi dasar hukum untuk diterapkan sebagai berikut ${ }^{30}$;

1. Sociological jurisprudence merupakan studi tentang dampak sosial aktual dari lembaga hukum dan doktrin hukum;

2. Sociological jurisprudence bertujuan untuk menghubungkan ilmu sosiologi dan ilmu hukum dalam persiapan legislasi";

3. Sociological jurisprudence merupakan studi yang berfokus pada cara untuk membuat aturan hukum efektif";

4. Sociological jurisprudence merupakan studi yang bukan hanya mengamati tentang bagaimana doktrin hukum itu berevolusi dan berkembang melainkan juga tentang bagaimana doktrin tersebut menghasilkan dampak sosialnya di masa lalu;

5. Sociological jurisprudence juga mendukung penerapan hukum yang adil dan memenuhi tuntutan keadilan antar pihak berdasarkan rasionalitias manusia biasa.";

6. Sociological jurisprudence merupakan bentuk upaya untuk mencapai keefektivitasan hukum.

Berdasarkan pemaparan penjelasan di atas, maka Inti dari Sociological jurisprudence adalah studi yang memandang bahwa sistem, doktrin dan lembaga hukum sebagai fenomena sosial yang dikritisi dan dikaji melalui kondisi, struktur, perkembangan sosial melalui pendekatan multidisiplin ilmu ${ }^{31}$. Bukan hanya itu, sociological jurisprudence juga bertujuan untuk menjembatani kesenjangan antara pemikiran hukum dan sosial secara langsung maupun tidak langsung ${ }^{32}$. Pada akhirnya, sociological jurisprudence menciptakan singkronisasi kepastian hukum (hukum positif) dengan living law (hukum yang hidup di dalam masyarakat) sebagai wujud pemenuhan akan kebutuhan

${ }^{25}$ Sucipto, U. Filsafat Hukum. (Yogyakarta: Deepublish, 2013), hlm. 54.

${ }^{26}$ Veitch, S., Christodoulidis, E., \& Farmer, L. Jurisprudence: Themes and Concepts, Second Edition (New York: RoutledgeCavendish, 2012), hlm. 123.

${ }^{27}$ Gurvitch, G. Sociology of Law (London: K. Paul, Tench, Trubner Press, 1947), hlm. ix.

28 Sucipto, Op. Cit.

${ }^{29}$ Tamanaha, B.Z. Sociological Jurisprudence Past and Present. Law \& Social Inquiry Vol 45, No. 2, (2020):520.

30 Pound, R. The Scope and Purpose of Sociological Jurisprudence. Harvard Law Review. Vol 25, No. 6, (1912): 489.

31 Ibid.

${ }^{32}$ Zamboni, M. Thoughts on Sociological Jurisprudence: Juristic Thought and Social Inquiry (Roger Cotterrell). Ratio Juris. Vol 32, No. 4, (2019): 497. 
masyarakat hukum dan penghargaan terhadap pentingnya peranan masyarakat dalam pembentukan dan orientasi hukum ${ }^{33}$.

\section{Sekilas Memahami Living Law}

Lahirnya living law bertolak dari kritik Eugen Ehlrich terhadap sistem hukum positif yang dirasa belum mampu menjalankan fungsi hukum dan pada akhirnya berkonsekuensi pada tidak tercapainya tujuan dari hukum itu sendiri. Oleh karenanya Ehlrich beranggapan bahwa hukum yang hakiki hanyalah hukum yang bersumber dari nilai-nilai yang melekat pada masyarakat itu sendiri. Ehrlich juga memandang bahwa kaeda-kaedah dan norma dogmatis hukum harus sesuai dengan nilai-nilai yang hidup dalam masyarakat. Meskipun demikian, bukan berarti Ehrlich sangat anti dengan sistem hukum positif sebagaimana yang sudah disalah pahami oleh banyak orang. Ehrlich dalam buku fenomenalnya yang berjudul "Fundamental Principles of the Sociology of Law" yang diterbitkan pada tahun 1913 menyimpulkan bahwa penerapan hukum di dunia terjadi lebih sedikit melalui sistem hukum positif daripada melalui living law ${ }^{34}$.

Eugen Ehlrich juga mengkritik para sejarawan yang tidak dapat mendefinisikan kriteria karakter hukum secara benar. Dimana para sejarawan gagal dalam menggabungkan metode dan prinsip yang berbeda dari persepsi ilmiah tentang hukum. Para sejarawan beranggapan bahwa hukum hanyalah sekedar norma hukum semata dan bukan berupa hubungan hukum sehingga mereka meninggalkan hubungan hukum yang sebenarnya (living law). Para sejarawan juga memandang hukum hanya berdasarkan tinjau historis semata. Padahal menurut Ehrlich hukum juga harus ditinjau secara sosiologis sehingga kritreria karakter hukum dapat didefinisikan secara ilmiah dan menyeluruh ${ }^{35}$.

Ehrlich merupakan bapak sosiologiawan hukum di era klasik sekaligus tokoh yang berperan besar terhadap lahirnya konsep ilmu living law. Gagasan akan konsep living law ia dapatkan dari doktrin Hermann Kantorowicz (18771940) seorang ahli sosiologi hukum asal jerman. Gagasan ini menyebar keseluruh dunia dan diterima oleh para ahli hukum mulai dari yang berlatar belakang ilmu sosiologi hingga ahli filsafat hukum. Di antara mereka adalah Nathan Roscoe Pound (1870-1964), Benjamin Nathan Cardozo (1870-1938), John Rogers Commons (1862-1945), Karl Nickerson Llewellyn (1893-1962), dan Thurman Wesley Arnold (1891-1969) yang berasal dari Amerika Serikat. Sedangkan di jerman ada nama-nama seperti Hermann Kantorowicz (1995-1963) dan Hugo Sinzheimer (1875-1945). Di prancis dikenal nama-nama seperti Leon Duguit (1859-1928), Maurice Hauriou (1856-1929), Maxime Leroy (18731957) dan Edgar Morin (1921- sekarang) ${ }^{36}$.

Konsepsi dari Living law adalah apa yang disebut oleh Friedrich Carl Von Savigny (1779-1861) "Das Recht Wird Nicht Gemacht, Est Ist Und Wird Mit Dem Volke" atau yang disebut juga oleh Eugen Ehrlich secara ringkas sebagai "all law is society's law". Suatu konsep yang dinilai oleh Roscoe Pound sebagai bentuk keberhasilan dalam menggunakan metodologi sosiologi yang sebenarnya sekaligus menjadi pembeda dengan pemikiran sosiologis sebelumnya (terutama terhadap madzhab sejarah yang cenderung abstrak) ${ }^{37}$.

Konsep yang dibawah oleh Ehrlich di atas pada dasarnya menjelaskan bahwa hukum yang sebenarnya yaitu hukum yang ada di masyarakat tertulis maupun tidak tertulis. Hukum masyarakat yang dimaksud adalah hukum yang sumbernya mengambil dari masyarakat yang sejak kelahirannya diasumsikan sudah membawa norma-norma bawaan yang mengatur dan membentuk perilaku setiap individu masyarakat. Norma-norma tersebut yang kemudian menjadi nilai-nilai bersamaan dengan etika dan adat kebiasaan yang dirasa adil dan diterima oleh masyarakat ${ }^{38}$.

Menurut Eugen Ehrlich nilia-nilai yang hidup dalam masyarakat bermula muncul dan terbentuk pertama kali dari asosiasi-asosiasi kecil di bawah jauh sebelum ditetapkan dan disahkan oleh negara seperti nilai-nilai dalam keluarga. Hingga kemudian semakin meluas dan mengarah ke atas yang ujungnya sampai pada asosiasi-asosiasi negara bahkan internasional. Nilai-nilai inilah yang diterima, diikuti dan dipatuhi masyarakat melalui kesadarannya tanpa diperlukan adanya paksaan. ${ }^{39}$

Namun konsep living law modern saat ini bukan hanya memandang pada nilai-nilai budaya atau adat istiadat suku lokal semata, melainkan mengambil nilai-nilai dari sub budaya lokal yang mungkin bisa jadi bertentangan jauh dari budaya induknya. ${ }^{40}$ Dan akhirnya nilai-nilai tersebut (budaya lokal maupun sub budaya lokal) bukan hanya sekedar

${ }^{33}$ Fuadi, M. Teori-Teori Besar (Grand Theory) Dalam Hukum. (Jakarta: Kencana, 2013), hlm. 248.

${ }^{34}$ Encyclopaedia Britannica. Eugen Ehrlich: Austrian legal scholar. Available from https://www.britannica.com/biography/Eugen-Ehrlich\#ref193345 (Diakses 10 September 2020)

${ }^{35}$ Arvatska, S. Socio-Historical Factors of Law Perception in "Living Law" Concept by Eugen Ehrlich. Ehrlich's Journal Ерліхівський журнал. 1, (2017): 51.

${ }^{36}$ Gurvitch, Loc.Cit., hlm. 51.

${ }^{37}$ Rahardjo, Loc.Cit., hlm. 98-99.

${ }^{38}$ Mansur, T.M. Hukum Adat: Perkembangan dan Pembaruannya (Banda Aceh: Syiah Kuala University Press, 2018), hlm.

81.

39 Ratnapala, S. Jurisprudence (Cambridge: Cambridge University Press, 2009), hlm. 13-14.

40 Luhmann, N. Law as Social System. (New York: Oxford University Press, 2004), hlm. 469. 
menjadi pedoman semata bagi masyarakat, melainkan juga legitimasi dari pemuka masyarakat setempat sebagai aturan yang mengikat yang harus ditaati.

Singkatnya, konsep living law adalah seperangkat ketentuan (hukum) yang kelahiran dan pembentukkannya bersamaan dengan lahirnya masyarakat. Mengandung nilai-nilai yang hidup di dalam masyarakat. Selalu menyatu dengan masyarakat. dan berfungsi untuk melayani kepentingan masyarakat ${ }^{41}$.

\section{Sociological Jurisprudence dan keefektivitasan hukum melalui living law}

Eugen Ehrlich sebagai pemikir sociological jurisprudence dan bapak dari living law mengatakan bahwa keberlakuan hukum positif dapat berjalan secara maksimal dan efektif apabila selaras dengan hukum yang hidup di

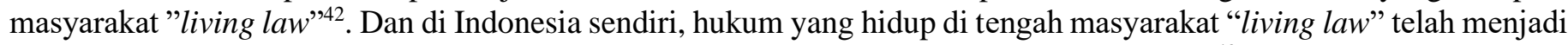
hukum yang sebenarnya dan cenderung lebih ditaati dengan baik oleh masyarakat Indonesia ${ }^{43}$.

Mochtar Kusumaatmadja juga mengemukakan persetujuannya terhadap pendapat dari Ehrlich di atas bahwa hukum positif karenanya akan sangat efektif terhadap suatu masyarakat apabila hukum tersebut sesuai dan tidak bertentangan dengan apa yang tercermin dalam nilai-nilai dalam suatu masyarakat tersebut (living law) ${ }^{44}$. Begitupula dengan apa yang diusahakan oleh Roscoe Pound ketika menguraikan tujuan dari Sociological jurisprudence yang salah satunya adalah menciptakan aturan hukum yang efektif tanpa harus dengan paksaan, ancaman. sanksi, dan menakutnakuti.

Ada alasan-alasan yang rasional mengapa masyarakat Indonesia khususnya akan mentaati hukum yang dibangun di atas living law tanpa harus menggunakan paksaan. yang di antaranya adalah pertama, karena sudah menjadi kebiasaan. Kedua, menghormati nilai-nila yang sudah ada dari nenek moyang (atau para pendiri negara). Ketiga, nilai-nila tersebut akan menjadi pengingat bagi seseorang di setiap kesempatan ${ }^{45}$.

Menurut Unger bahwa keefektivan hukum hanya dapat terlaksana secara alami. Sehingga segala macam paksaan dari luar justru sangat tidak berpengaruh. savigny juga menambahkan bahwa keefektivan hukum itu muncul atas motivasi dari dalam (masyarakat) ${ }^{46}$. Oleh karenanya keefektivitasan hukum bisa direalisasikan dengan cara sebagaimana berikut:

Pertama, memasukkan nilai-nilai yang hidup di dalam masyarakat di dalam sebuah hukum. Hal ini dinilai efektif karena mencapai keselarasan antara keputusan teknokrat dan keinginan rakyat ${ }^{47}$. Oleh karenanya menurut H.C. Kelman dan Leopold pospilis kepatuhan masyakarat terhadap hukum itu bisa jadi karena beberapa faktor,yang salah satunya adalah karena sesuai dengan nilai-nilai dari masyarakat dan menjamin kepentingan-kepentingan mereka ${ }^{48}$.

Sebagai kaidah sosial, hukum merupakan cerminan terhadap nilai-nilai yang berlaku di masyarakat dan hanya akan dianggap baik dan efektif ketika mengandung nilai-nilai tersebut. Sehingga bagi negara dan bangsa Indonesia yang masih mengembangkan hukum nasional tentu harus dilandasi dengan nilai-nilai yang ada dan dianut dalam masyarakat "living law". Nilai-nilai tersebut juga bisa dikombinasikan dengan nilai-nilai yang berkembang lainnya yang sesuai dengan kultur masyarakat Indonesia seperti nilai-nilai Pancasila, keagamaan, kemanusiaan dan lainnya yang juga dianggap oleh masyarakat.

Kedua adalah memperhatikan fakta-fakta sosial mulai dari dalam pembuatan, penafsiran, hingga penerapan peraturan-peraturan Hukum. Karena pada dasarnya konsep dasar dari Sociological Jurisprudence sebenarnya diawali dengan melihat pentingnya realitas (fakta) kehidupan sebagai pembentuk hukum, yaitu fakta atau realitas yang merupakan akumulasi dari seluruh hubungan-hubungan yang telah ada dan terpola di dalam kehidupan masyarakat ${ }^{49}$.

Oleh karena itu Cardozo menyarankan bahwa setiap pakar hukum, pembuat hukum hingga penegak hukum dituntut untuk mempertajam kepekaan hukum pada realitas dan fakta sosial. Indikasi bahwa hukum akan efektif apabila

${ }^{41}$ Hadi, S. "Hukum Positif dan The Living Law (Eksistensi Dan Keberlakuannya Dalam Masyarakat)". DiH Jurnal Ilmu Hukum Vol 13, No. 26, (2017): 266.

${ }^{42}$ Suliantoro, B.W. "Dinamika Arah Kepastian Hukum Di Tengah Transformasi Sosial-Budaya Dalam Perspektif Pemikiran Mazhab Sociological Jurisprudence”. Jurnal Filsafat Vol 17, No. 1, (2017): 31.

${ }^{43}$ Yuningsih, D. "The Essence Of Justice For The Living Law In The Alternative Dispute Resolution Of Indonesia Legal System". International Journal of Approximate Reasoning Vol 5, No. 3, (2017): 1930.

${ }^{44}$ Wiranata, I.G.A.B. Hukum Adat Indonesia Perkembangan dari Masa ke Masa (Bandung: Citra Aditya Bakti, 2005), hlm. 298.

45 Ibid, hlm. 12.

46 Rahardjo, Loc. Cit., hlm. 187-188.

47 Halim, Y., Sudewo, F., Justian, J. "Transformative-Participatory Legal Research Method for Harmonizing the Existence of the Living Law in Indonesia". Media Hukum. Vol 26 No. 2, (2019): 157.

${ }^{48}$ Suadi, A. (2018). Sosiologi Hukum: Penegakan, Realitas dan Nilai Moralitas Hukum. Jakarta: Kencana, h. 24-25.

${ }^{49}$ Junaidi, Op.Cit. 
terdapat kesesuaian antara standar yang diakui oleh masyarakat dengan nilai-nilai dan fakta-fakta objektif dari hukum positif $^{50}$.

Sebagaimana perkembangan awal sosiologis hukum, gagasan living law atau gagasan yang serupa dengannya memiliki pengaruh yang sangat besar terutama dikarenakan living law disajikan sebagai kendali yang tak terelakkan atas apa yang harus dilakukan oleh hukum negara ${ }^{51}$.

Ketiga adalah dengan mendengarkan dan merealisasikan setiap aspirasi dan partisipasi dari masyarakat dalam pembentukan perundang-undangan. Sebagai negara hukum yang demokratis, Pembentukan peraturan perundangundangan di Indonesia tentunya tidak lagi semata-mata menjadi wilayah dominasi eksekutif (birokrat) dan parlemen, namun juga sudah menjadi bagian dari tanggung jawab masyarakat untuk berpartisipasi di dalamnya ${ }^{52}$.

Dalam Pasal 109 (8) Peraturan Dewan Perwakilan Rakyat Republik Indonesia Nomor 1 Tahun 2014 Tentang Tata Tertib juga disebutkan bahwa aspirasi masyarakat menjadi dasar dalam pembahasan Prolegnas, penyusunan daftar rancangan undangundang. Sehingga masyarakat juga harus diundang dalam rapat dengar pendapat umum untuk mendapatkan masukan terhadap rancangan undang-undang yang sedang dibahas ${ }^{53}$.

Adapun bentuknya, maka hukum postif telah mengatur tentang tata cara pemberian aspirasi dan partisipasi masyarakat. Misalnya saja pada pasal 96 ayat (1) UndangUndang Nomor 12 Tahun 2011 tentang Pembentukan Peraturan Perundang-Undangan dinyatakan bahwa: "Masyarakat berhak memberikan masukan secara lisan dan/ atau tertulis dalam Pembentukan Peraturan Perundang undangan". Selanjutnya pada Pasal 96 ayat (2) disebutkan bahwa partisipasi masyarakat tersebut dapat dilakukan melalui:

(a) Rapat dengar pendapat umum;

(b) Kunjungan kerja;

(c) Sosialisasi; dan/ atau

(d) Seminar, lokakarya, dan/ atau diskusi.

Dalam negara demokrasi kedudukan masyarakat (rakyat) memiliki kedudukan tertinggi. Aspirasi mereka merupakan hak yang harus didengarkan dan dipenuhi. Serta partisipasi mereka harus dilibatkan dalam segala aspek. Oleh karenanya, bagi negara Indonesia yang menganut sistem politik demokrasi dengan sistem hukum civil law melibatkan masyarakat dan mendengarkan partisipasi mereka dalam proses pembentukan peraturan perundangundangan merupakan suatu keharusan dan satu kesatuan yang tidak dapat dipisahkan.

Masyarakat akan jauh lebih berpengaruh dan lebih tangguh ketika berpartisipasi dan berkontribusi langsung pada pembuatan kebijakan dan peraturan perundang-undangan yang mempengaruhi kehidupan mereka ${ }^{54}$. Hal ini selain untuk membuat hukum yang selaras dengan apa yang dikehendaki oleh masyaraskat, juga akan menciptakan keefektivitasan hukum itu sendiri secara maksimal.

Terakhir adalah dengan menerapkan konsep dari apa yang disebut oleh Pound sebagai " a tool of social enggenering" yaitu menjadikan hukum sebagai alat (sarana) untuk memperbaharui, merekayasa atau mengubah (perilaku) masyarakat. Teori law as a tool of social enggenering berawal dari fakta bahwa setiap masyarakat akan terus mengalami perubahan cepat maupun lambat. Perubahan yang terjadi di tengah masyarakat bisa terjadi karena perubahan kondisi geografis, budaya material, komposisi demografi, ideologi, dan juga penemuan baru dalam masyarakat. Dalam ilmu sosial, keadaan tersebut dipandang sebagai keadaan yang digambarkan dalam masyarakat yang dinamis sehingga tindakan seseorang tidak mungkin hanya didorong oleh pertimbangan individu semata, melainkan juga dengan apa yang diharapkan orang lain darinya. Tindakan seseorang tidak berdiri sendiri, tetapi diatur dalam rangkaian sistem peran yang diharapkan atau ekspektasi peran ${ }^{55}$.

Konsep dari law as a tool of social enggenering menurut Roscoe Pound juga bagaimana hukum mampu menjaga dan menjamin kepentingan-kepentingan tertentu secara seimbang. dalam hal ini, Pound membagi kepentingan tersebut kedalam tiga kategori. Pertama, kepentingan individu yang merupakan keinginan yang langsung terlibat dalam kehidupan individu dan cenderung masuk dalam ruang lingkup hukum privat (private law). Kedua, kepentingan yang berkaitan dengan publik dan hukum public (Public Law). Kepentingan ini berkaitan juga dengan kehidupan politik yang

\footnotetext{
${ }^{50}$ Suliantoro, Op.Cit.
}

${ }^{51}$ Cotterrell, R. "From Living Law to Global Legal Pluralism: Rethinking Traditions from a Century Of Western SocioLegal Studies”. Queen Mary School of Law Legal Studies Research. No. 229, (2015): 4.

52 Tim Pengkajian Hukum KemenkumhamRI. Laporan Akhir Pengkajian Hukum Tentang Partisipasi Masyarakat Dalam Penentuan Arah Kebijakan Prioritas Penyusunan Peraturan Perundang-Undangan. Kementerian Hukum Dan Hak Asasi Manusia RI, (2014), h. 6.

${ }^{53}$ Pasal 145 (1) Peraturan Dewan Perwakilan Rakyat Republik Indonesia Nomor 1 Tahun 2014 Tentang Tata Tertib

${ }^{54}$ Guterres, A. "The Highest Aspiration A Call To Action For Human Rights". United Nation, (2020): 8.

${ }_{55}$ Matnuh, H. "Law as a tool of social enggenering". Advances in Social Science, Education and Humanities Research (ASSEHR), v.147, (2017): 120. 
diinginkan dan diharapkan oleh masyarakat. Dan yang terakhir adalah kepentingan sosial yang didefinsiiakn sebagai keinginan dan tuntutan yang setiap individu dalam masyarakat dalam kehidupan sosial mereka ${ }^{56}$.

\section{SIMPULAN}

Konsep keefektivitasan hukum adalah bagaimana hukum mampu menjalankan fungsinya untuk mencapai tujuannya. Hukum dalam Sociological jurisprudence difungsikan sebagai kontrol dan rekayasa sosial. Sociological jurisprudence juga memandang bahwa hukum tidak lagi dipandang sebagai paksaan monopolis dari suatu kekuasaan yang justru hanya akan menimbulkan pertentangan dan pemberontakkan. Hukum harus dilihat dari sekumpulan nilainilai yang sudah lama melekat dalam masyarakat sehingga hukum akan dipatuhi oleh masyarakat itu sendiri, sehingga hukum menjadi efektif dalam menjalankan fungsinya dan hukum akan terjaga kewibawaannya.

Nilai-nilai yang dimaksudkan adalah sebagaimana yang dijelaskan dalam konsep living law yaitu mecakup norma-norma, moral, dan etika. Dan inilah yang pada akhirnya menjadi suatu hukum yang sesungguhnya baik tertulis maupun tidak. Pada akhirnya, nilai-nilai ini tidak hanya menjadi suatu pedoman semata, tapi juga legitimasi terhadap aturan yang berlaku.

Sehingga pada akhirnya keefektivitasan hukum dapat diciptakan berdasarkan empat hal, yaitu dengan nilai-nilai, fakta-fakta, aspiras-aspirasi dan juga kepentingan-kepentingan yang berkaitan dengan masyarakat sebagai individu dalam bersosial dan ranah public. Keempat hal tersebut harus dimasukkan dan diikutsertakan dalam pembuatan, penafsiran, hingga penerapan peraturan-peraturan Hukum terhadap masyarakat yang pada dasarnya merupakan sasaran dari aturan hukum itu sendiri.

\section{DAFTAR PUSTAKA}

\section{Buku}

Bodenheimer, E. Jurisprudence: The Phiolosphy and Method of the Law. London: Harvard University Press, 1947. Fuadi, M. Teori-Teori Besar (Grand Theory) Dalam Hukum. Jakarta: Kencana, 2013.

Gurvitch, G. Sociology of Law. London: K. Paul, Tench, Trubner Press, 1947.

Irianto, S., Shidarta. Metode Peneltian Hukum: Konstelasi dan Refleksi. Jakarta: Yayasan Pustaka Obor Indonesia, 2009. Kusumaatmadja, M. Fungsi dan Perkembangan Hukum dalam Pembangunan Nasional. Bandung: Bina Cipta, 1976.

Luhmann, N. Law as Social System. New York: Oxford University Press, 2004.

Mansur, T.M. Hukum Adat: Perkembangan dan Pembaruannya. Banda Aceh: Syiah Kuala University Press, 2018.

Martin Krygier. "Rule of Law (and Rechtsstaat)." dalam James Wright (Eds), International Encyclopedia of the Social \& Behavioral Sciences: Second Edition (Amsterdam: Elsevier, 2015)

Mertokusumo, S. Mengenal Hukum: Suatu Pengantar. Yogyakarta: Liberty, 2008.

Morrison, W. Jurisprudence: from the Greek to Post-Modernism. London: Routledge, 2005.

Rahardjo, S. Sosiologi Hukum: Perkembangan, Metode, dan Pilihan Masalah. Surakarta: Muhammadiyyah University Press, 2002.

Rahardjo, S. Hukum dan Perilaku: Hidup Baik adalah Dasar Hukum Yang Baik. Jakarta: PT. Kompas Media Nusantara, 2009.

Rahardjo, S. Ilmu Hukum. Bandung: PT. Citra Aditya Bakti, 2012.

Ratnapala, S. Jurisprudence. Cambridge: Cambridge University Press, 2009.

Suadi, A. Sosiologi Hukum: Penegakan, Realitas dan Nilai Moralitas Hukum. Jakarta: Kencana, 2018.

Sucipto, U. Filsafat Hukum. Yogyakarta: Deepublish, 2013.

Veitch, S., Christodoulidis, E., \& Farmer, L. Jurisprudence: Themes and Concepts, Second Edition. New York: Routledge-Cavendish, 2012.

Wiranata, I.G.A.B. Hukum Adat Indonesia Perkembangan dari Masa ke Masa. Bandung: Citra Aditya Bakti, 2005.

Wirawan. I.B. Teori-Teori Sosial dalam Tiga Paradigma: Fakta Sosial, Definisi Sosial dan Perilaku Sosial. Jakarta: Kencana, 2012.

\section{Jurnal}

Buckley, F.H. The Revival of Sociological Jurisprudence. The Journal of Socio-Economics, Vol 22 No. 4, (1993):197.

Cotterrell, R. From Living Law to Global Legal Pluralism: Rethinking Traditions from a Century Of Western SocioLegal Studies. Queen Mary School of Law Legal Studies Research. No. 229. (2015).

Hadi, S. Hukum Positif Dan The Living Law (Eksistensi Dan Keberlakuannya Dalam Masyarakat). DiH Jurnal Ilmu Hukum Vol 13, No. 26, (2017): 266.

\footnotetext{
56 Pound, R. “A Survey of Social Interests”. Harvard Law Review. Vol 57, No. 1, (1943): 39.
} 
Wempy Setyabudi Hernowo, Zaid, dan M. Aufar Saputra Pratama Erawan. Peran Sociological Jurisprudence Dalam Menciptakan Keefektivitasan Hukum Melalui Living Law

Halim, Y., Sudewo, F., Justian, J. Transformative-Participatory Legal Research Method for Harmonizing the Existence of the Living Law in Indonesia. Media Hukum Vol 26, No. 2, (2019): 157.

Hamzani, A.I., Aravik, H., Mukhidin, M., \& Praptono, E. Considering the Living Law as A Source in National Legal Development. Jurnal Cita Hukum Vol 7, No. 2, (2019): 190.

Langone, Richard. The Science of Sociological Jurisprudence as a Methodology For Legal Analysis. Touro law review Vol 17, No. 5, (2016): 800.

March, J.G. Sociological Jurisprudence Revisited, A Review (More or Less) of Max Gluckman. Stanford Law Review Vol 8, No. 3,(1956): 534.

Matnuh, H. law as a tool of social enggenering. Advances in Social Science, Education and Humanities Research (ASSEHR), Vol 147, (2017): 120.

Pound, R. The Scope and Purpose of Sociological Jurisprudence. Harvard Law Review Vol 25, No. 6, (1912): 516.

Pound, R. A Survey Of Social Interests. Harvard Law Review Vol 57, No. 1, (1943): 39.

Přibáň, J. Roger Cotterrell: Sociological Jurisprudence: Juristic Thought and Social Inquiry. Journal of Law and Society Vol. 45, No. 2, (2018): 337.

Suliantoro, B.W. Dinamika Arah Kepastian Hukum Di Tengah Transformasi Sosial-Budaya Dalam Perspektif Pemikiran Mazhab Sociological Jurisprudence. Jurnal Filsafat Vol 17, No. 1, (2017): 31.

Tamanaha, B. Z. Sociological Jurisprudence Past and Present. Law \& Social Inquiry, Vol 45, No. 2, (2020): 520.

Tim Pengkajian Hukum KemenkumhamRI. (2014). Laporan Akhir Pengkajian Hukum Tentang Partisipasi Masyarakat Dalam Penentuan Arah Kebijakan Prioritas Penyusunan Peraturan Perundang-Undangan. Kementerian Hukum Dan Hak Asasi Manusia RI. (2014).

Yuningsih, D. The Essence Of Justice For The Living Law In The Alternative Dispute Resolution Of Indonesia Legal System. International Journal of Approximate Reasoning, Vol. 5, No. 3, (2017): 1930.

Zamboni, M. Thoughts on Sociological Jurisprudence: Juristic Thought and Social Inquiry (Roger Cotterrell). Ratio Juris Vol 32, No.4, (2019): 497.

\section{Peraturan Perundang-Undangan}

Peraturan Dewan Perwakilan Rakyat Republik Indonesia Nomor 1 Tahun 2014 Tentang Tata Tertib

Undang-Undang Dasar Negara Republik Indonesia Tahun 1945.

UndangUndang Nomor 12 Tahun 2011 tentang Pembentukan Peraturan Perundang-Undangan

Website resmi:

Encyclopaedia Britannica. (2020). Eugen Ehrlich: Austrian legal scholar. Available from https://www.britannica.com/biography/Eugen-Ehrlich\#ref193345 (Diakses 10 September 2020).

Guterres, A. (2020). The Highest Aspiration A Call To Action For Human Rights. United Nation. Retrieved from https://www.un.org/sg/sites/www.un.org.sg/files/atoms/files/The_Highest_Asperation_A_Call_To_Action_Fo r_Human_Right_English.pdf (Diakses 15 September 2020).. 